Article

\title{
The Alfredo Namitete Agroecology Credit System: A New Business Model That Supports Small-Scale Lending
}

\author{
Angela Hilmi \\ Centre for Agroecology, Water and Resilience, Coventry University, Ryton Gardens, Wolston Lane, Coventry, \\ Warwickshire CV8 3LG, UK; angela.hilmi@coventry.ac.uk
}

Received: 17 June 2019; Accepted: 24 July 2019; Published: 27 July 2019

\begin{abstract}
A major obstruction in the development of sustainable agriculture is the weakness of the financial and banking sectors in supporting smallholder farming. While farmers need to invest in their farms, they struggle to find credit schemes adapted to their specific needs. This study explores the literature on a range of credit systems applied in different geographical and historical contexts to analyse the underlying drivers of their successes or otherwise. In light of this review, the study investigates a farmers' association, Alfredo Namitete (AN), in Mozambique, offering a range of agroecology credit modalities. It is then assessed as to whether a new business model initiated with seed funding could be self-managed by the association itself and lead to greater autonomy. The AN pilot tested three schemes between 2015 and 2019. Based on the findings, i.e., better production, increased revenue and greater self-determination, the study combines elements for a new business model for small-scale lending. It concludes that to be effective, a credit scheme needs to meet several conditions simultaneously: believe in the genuine will to repay, abolish the lender-borrower distance, ensure a role for women in decision making, add a savings mechanism, combine individual and collective investments and, finally, reserve funds for solidarity and climate issues.
\end{abstract}

Keywords: Credit systems; autonomy; agroecology; smallholder; farmer; peasant; individual; collective; inclusive; investment; sustainable agriculture; finance

\section{Introduction}

The importance of agriculture for the well-being of human societies is widely recognised [1-7]. The International Assessment of Agricultural knowledge, Science and Technology for Development (IAASTD) is the most comprehensive agriculture study ever made. It stresses the need to rethink our global food systems so that they can feed people, create healthy communities and economies and sustain the planet. Agriculture provides food, animal feed, fibre, fuel and other goods. It has a major influence on ecosystem services such as water and carbon. It plays an important social role in providing employment and a way of life and it represents a medium of cultural transmission worldwide. Agriculture-based communities provide a foundation for local economies [8-10] and public goods for societies at large [11].

Although small farms represent more than $85 \%$ of the world's farms $[1,10,12]$ and small food producers represent almost half the world's population [13], there is no financial instrument dedicated to their specific needs. The key obstruction to stimulating investment is the weakness of the financial and banking systems in supporting smallholder agriculture. This has been highlighted by the High-Level Panel of Experts of the Committee on Food Security, an intergovernmental body that reviews world food policies [14]. Farmers' decisions remain intimately dependent on credit constraints (e.g., collateral requirement and associated risks), with smallholder farmers in a disadvantaged position [15]. 
Following the 2008 world financial and economic crises, priority was given in the corporate world to governance, environmental and social practices (CESPs), in the context of organizational resilience, to cope more positively with unexpected shocks [16]. In agriculture, attempts were made to develop innovative inclusive models and to explore different, more resilient patterns with private capital investment [17-22]. However, unequal negotiating power and challenges of replicability and scalability limited their application [23]. While there was a growing interest from private investors in targeting the developing world's agriculture, agribusiness investments were preferred as they were set up for profitability and the investments did not benefit the primary producers [24]. Similarly, reviews of inclusive models used in production agriculture in developing countries show that they mainly target outgrower schemes on a few selected cash crops [21], without benefiting peasant farming.

There remains limited empirical knowledge about the factors (including policies) that either encourage or constrain on-farm investments, especially for smallholder farmers. Studies have shown that farmers are by far the principal source of investment in agriculture [25]. On-farm investments are more than three times larger than all other sources of investment combined. Annual investment in on-farm agricultural capital stock exceeds government investment by more than four to one and other resource flows by a much larger margin [25]. Levels of Foreign Direct Investment are limited when compared to other types of investment and their increase is overstated. Critical gaps however remain about on-farm investment and suitable credit systems for smallholder farmers. A new business model that can support small-scale lending is yet to be born.

The main purpose of this study is to explore different forms of credit allocation with peasant communities that can suit their specific needs. The core aim is to test whether farmers' associations can self-manage their own credit systems and whether this process can lead to greater autonomy. It is hoped that these explorations will provide new insights into devising a new business model for small-scale lending dedicated to peasant farming. Section 1 reviews selected credit schemes in different historical and geographic contexts to identify the underlying reasons for their success or otherwise. Section 2 presents the method used in the pilot to test the credit schemes with farmers in the field. Section 3 summarises the results of the pilot and Section 4 provides elements of a discussion to contrast the empirical outcomes in light of the literature review. In the Conclusion, elements are proposed for a new perspective on a credit scheme dedicated to peasant farming.

\section{A Review of Credit Schemes}

The study of credit schemes for smallholder farmers presents a number of challenges. Agricultural credit from formal institutions is often inaccessible to peasants in that it requires both collateral and adherence to a number of rules and regulations which are often incompatible with their way of farming. Informal credit can have unreasonably high interest rates. Although it partially satisfies some of the farmers' requirements (mainly small agricultural inputs and fulfilling consumption needs), it is often used piecemeal and is not specifically designed to support the development of sustainable agriculture. On the other hand, there are credit schemes designed for the poor, many of whom are smallholders. These are used by farmers with differing levels of success, but again they present a number of drawbacks in that they normally require monthly payments, which are not suitable in an agricultural context. They are more adapted to small businesses and self-developed micro-enterprises. Farmers therefore are left with a range of choices, which are more or less suited to their needs. They often combine them in the best possible way to reduce risk, while trying to access some means to invest in their farms. It is known that credit is a necessity for farmers [14], who are de facto the biggest investors in agriculture [25]. However, credit requirements differ in that agriculture is different to any other human economic activity, as it is intimately connected to weather events and production cycles [26,27]. Agriculture is characterised by fluctuating periods of abundance and scarcity, which can benefit families and society as a whole over a longer period of time, but which cannot be restricted to a one-year calendar cycle [10]. Farming means working with nature and has a different time scale [3]. 
Agroecology $[10,28-30]$ was defined as the application of ecological concepts and principles to the design and management of sustainable agroecosystems. It is the agricultural model used in the pilot testing in this research. It is particularly appropriate in that it is a model of sustainable agriculture that protects the environment (soil, water, carbon, climate, etc.) and produces quality products. Morover, agroecology does not require high external inputs, thus reducing the need for external financing. Different credit schemes have been tested with Alfredo Namitete, a farmers' association in Mozambique (from 2015 to 2019), to identify what model would best fulfil the needs and aspirations of its members and lead to greater autonomy and self-determination, while at the same time contributing to the development of sustainable agriculture.

The literature review assesses different credit schemes applied in different geographical [29-34], and historical contexts [35-38], to analyse the range of options available to farmers. Literature of the past 10 years was reviewed, featuring a wide range of financial schemes including public and private credit, formal and informal schemes, credit for farmers and credit for the poor, microfinance and different inclusive models for agricultural development. The most relevant examples were selected in terms of information on successes and failures. The characteristics of these different models were then analysed and compared, with a view to creating a new business model serving the needs of smallholders. The schemes were clustered into four groups, from less adapted to most adapted to smallholder needs, then contrasted with the findings of the pilot project in Africa. It is hoped that this work can provide some useful insights into the post-microfinance revolution, to serve the creation of more successful farming systems. The basic results of this review are presented in Table 1:

Table 1. Cluster of schemes.

\begin{tabular}{|c|c|c|c|c|c|}
\hline & Collateral & Distance (D) & $\begin{array}{l}\text { Time for Loan } \\
\text { Approval }\end{array}$ & $\begin{array}{l}\text { Transaction } \\
\text { Costs }\end{array}$ & $\begin{array}{c}\text { Flexibility on } \\
\text { Repossession of Assets } \\
\text { and Admin Work }\end{array}$ \\
\hline $\begin{array}{l}\text { 1-Formal credit } \\
\text { with collateral }\end{array}$ & $\begin{array}{l}\text { YES } \\
\text { required }\end{array}$ & $\begin{array}{c}\text { Long D } \\
\text { Centralized bank } \\
\text { office }\end{array}$ & $\sim 6$ to 12 months & High & NO \\
\hline $\begin{array}{l}\text { 2-Flexible } \\
\text { credit } \\
\text { conditions }\end{array}$ & Preferred & $\begin{array}{c}\text { Medium D } \\
\text { Decentralized bank } \\
\text { office }\end{array}$ & 2 to 4 months & Medium & YES \\
\hline $\begin{array}{l}\text { 3-Peer group } \\
\text { as guarantee }\end{array}$ & $\mathrm{NO}$ & $\begin{array}{c}\text { Close D } \\
\text { Local group of } \\
\text { villages office } \\
\text { branch }\end{array}$ & 1 to 3 months & Medium low & YES \\
\hline $\begin{array}{l}\text { 4-Integrated } \\
\text { scheme with } \\
\text { self-financing }\end{array}$ & $\mathrm{NO}$ & $\begin{array}{l}\text { Self-managed } \\
\text { locally }\end{array}$ & $\begin{array}{l}\text { Less than a } \\
\text { month }\end{array}$ & Low & YES \\
\hline
\end{tabular}

The different clusters are now presented in detail with examples.

\subsection{Formal Credit with Collateral}

The first obstacle for farmers in borrowing from the formal sector is collateral, which determines whether or not a client is "bankable" [26]. Collateral remains at the centre of policy debates about failing to reach the poor [39]. What characterises credit is the fact that lenders cannot know the borrowers' intentions or their ability to repay a loan [26]. In addition, farmers struggle to access formal credit because of the need to travel back and forth to the bank, the burden of paperwork and the time it will take for the bank to approve the loan. This first model is characterised by the need for collateral, stringent controls, high transaction costs (in preparing, approving and following loan contracts), a lack of flexibility in repayment schedules, limited information about a client's operations and finally distance (both physical and in terms of power relationships) between lender and borrower. Major large, government- subsidised schemes follow this model with variable enforcement rules and procedures. Some examples are outlined as follows. 
In China, state-owned formal financial institutions such as the Agricultural Bank of China and the Rural Credit Cooperative dominate institutional lending in rural economies. These are heavily subsidised by the government to support agricultural production [40]. Although the demand for credit is immense and has significantly increased in recent years, the use of formal finance is stagnating [34,40,41]. In Iran, the Keshavarzi Bank (Agribank), is the main financial and credit institution providing approximately $70 \%$ of agricultural credit to farmers. A significant number of the farmers receiving agricultural loans use them in other sectors for consumption and subsistence needs [33]. In Pakistan, a scheme launched by the State Bank for smallholders was not successful because it was conditioned to collateral and security, whereas $92 \%$ of smallholder farmers rely on informal credit sources [36]. In the Russian federation, government grants provided to regional agricultural development programmes have been ineffective, as access conditions remain too stringent and do not consider the seasonality of agriculture and the uneven use of resources during the year [27]. In Brazil, PRONAF (Programa Nacional de Fortalecimento da Agricultura Familiar) aims to reach out to family farmers throughout the country but has mainly targeted resources to more capitalised farmers for commodity production, particularly in the south, south-east and centre-west [42].

\subsection{Flexible Credit Conditions}

This is a different model in which banks dedicate their lending to suit farmers, the landless or the poor, adjusting their standard rules and adding flexibility accordingly. This was the case in France at the turn of the nineteenth century, when the government played a proactive role in attending farmers' needs and directed its central bank to support the development of agriculture [37]. Security bonds were offered and passed on to the regional banks as security, which in turn, provided mid-term loans to farmers. The Bank of France would overlook the risk and discount notes on request (the French code did not allow farmers to be made bankrupt), and the notes would then be renewed to suit the agricultural calendar. For landless shareholders, chattel requirements were omitted and instead, their honesty, industry and character were considered [37].

More recently in Chile, the government has developed a credit scheme whereby $90 \%$ of the Agricultural Ministry's budget is dedicated to the agricultural development institute (INDAP) to provide loans and technical assistance to farmers [43]. The INDAP was able to reach out to $65 \%$ of the total number of farms in the country, showing a repayment rate of $92 \%$ (2018 figures). The programme is characterised by a high number of decentralised offices, an emphasis on technical assistance, shared responsibility and flexible repayments or debt cancelling, in case of force majeure. The model is used in countries including Costa Rica, Paraguay and Argentina.

The century-old Bank Rakyat Indonesia (BRI) is another successful case related to microcredit, adding a key component: the savings account [39]. In 1984, the BRI microbanking units were transformed from channels of subsidised targeted credit into savings-led profit-oriented financial intermediaries. Under the new organisational system, the units had their own administrative structure. All government and donor-supported programmes were handled by the branches. The units moved from a commodity approach to considering any creditworthy person for any income-generating activity. BRI has grown to be the most profitable bank in Indonesia. It has the largest loan portfolio and the biggest outreach (a saver outreach of 21.2 million accounts, a savings portfolio of USD 8 billion and a borrower outreach of 4.7 million) [39]. BRI has grown into the developing world's largest sustainable banking system. The reformed units were based on core principles of autonomy, savings-based self-reliance, profitability and inclusive national outreach. While BRI requires that clients pledge collateral, the centre of lending decision is based on potential future household income flow in contrast to relying on sizable assets in case of default. Thus, the bank would rarely take legal action to possess any assets. Its success therefore is based on flexibility, both in collateral and in administrative paperwork. 


\subsection{Peer Group as Guarantee}

The third model does not imply any collateral. It was promoted in the following two examples by individuals concerned with poverty who devised two distinct schemes that have had significant impact worldwide. Frederick William Raiffeisen in Germany, whilst still very young, founded the Bread and Fruit pre-cooperatives for self-procurement in 1849, based on the principle of benevolent assistance. He believed that there was a connection between poverty and dependency. To address poverty, dependency should first be dealt with through the $3 S$ formula: self-help, self-governance and self-responsibility. Independence from charity, politics and loan sharks were found to be necessary. Capital was obtained from members' deposits who would gain interest in return. Raiffeisen banks became The People's Bank, a concept which would spread throughout Europe and beyond. The downfall of the model however was the insufficiency of capital to service the loans [37].

The second scheme was the Grameen Bank (GB), founded by Muhammad Yunus, in Bangladesh, who received the 2008 Nobel Price. He considered that credit should be a human right, which suggests an imperative to make lending universal [44]. He confronted conventional banking practices by classifying those that rejected the poor as not creditworthy. In his view, loans were designed to help people help themselves, creating the opportunity for income-generating activities and self-employment. Collateral is therefore eliminated, and members of the group guarantee each other's loans. A microfinance scheme applied in China, known as the CFPA (Foundation for Poverty Alleviation) added a new layer of flexibility by providing loans that could be used for production as well as consumption needs in order to meet the demands of farmers. Its success is exemplified by a repayment rate of $97.4 \%$ against $4.9 \%$ for formal credit [40]. The main obstacle however is that the supply of funds is insufficient for the demand.

\subsection{Integrated Scheme with Self-Financing}

The fourth model is the Homeland Coffers, based on capital accumulation designed to be self-financing. It is the agricultural credit system founded by Midhat Pasha between 1863 and 1888, under the Ottoman Empire [38]. At that time, Ahi Unions were the first examples of cooperatives in Anatolia, dating from the thirteenth century. They were a form of craftsmens' associations based on the Ahi philosophy, a mixture of Islamic values and pre-Islamic Turkish traditions. They had common funds, mutual assistance funds and social assistance funds to protect their members. Midhat Pasha (1822-1883), the Grand Vizier under Sultan Abdülaziz and Sultan II Abdülhamit, had the idea of adapting this approach to farmers. During the nineteenth century, agriculture was the primary growth sector in the Ottoman economy. Small farms were predominant. The land was owned by the Empire, but peasants had use rights. However, loan sharks would lend money to farmers at high interest rates. In 1863, Midhat Pasha initiated a new credit cooperative called Memleket Sandigi (Homeland Coffers) to test low interest rate loans for farmers. The capital came from their contributions. Midhat Pasha then added infrastructure investments, connecting rural and urban areas. Markets changed from subsistence to commercial and the result was a great success. A Homeland Coffers law came into force in 1865 (29 articles, on capital accumulation, management, lending conditions, profit sharing, and accounting). What Midhat Pasha created had existed nowhere else in Europe. Its originality and its difference from other credit cooperatives was the capital provision method. The income for the Coffers was provided through common efforts of farmers and returned to them as credit. It used the cooperative principles and values of self-help, democracy, equality, equity and solidarity.

\subsection{Articulation between the Credit Schemes}

To summarise the articulation between these selected examples from the literature, it can be said that credit in early nineteenth-century Europe was a reaction to excessive interest rates and was characterised by self-help and mutual guarantee, with capital coming from the members' deposits [35]. The downside was the availability of capital, which soon became insufficient to cover the demand for 
credit. Some governments became involved and created reserve funds and others took a pro-farmer stance and directed central banks to subsidise and facilitate flexible credit access. The absence of collateral was overcome by personalised credit allocation, whereby the identity (genuine will and capacity) of the lender became a key criterion for credit approval [37].

More recently, governments in many countries have launched pro-farmer initiatives including some vast agricultural credit programmes. These are usually subsidised, with massive financial flows also provided by bilateral and international agencies [45]. The major obstacle however is the need for collateral, which has often resulted in a lack of access for the poor, excessive indebtedness and loss of assets for those unable to repay the loans [46]. Some organisations have addressed the problem in different ways; for example BRI has opted for being flexible on collateral, giving more importance instead to the client's potential, relying on savings as the source of capital; thus moving from a credit-only approach to savings-and-credit [39]. The INDAP in Chile combines credit with technical assistance, support for marketing the produce, co-responsibility with reimbursement and support in case of repayment failure independent from the will of the borrower, such as force majeure [43]. The Grameen Bank's microfinance takes a firm stand against collateral, relying instead on trust and group lending, proposing a different methodology with special loan conditions and a simultaneous social development agenda [47]. The CFPA in China takes this a step further to benefit farmers with repayment periods and schedules that are better suited to the production calendar [40].

The literature reveals that the poor have active financial lives, that they co-hold debt and savings and that there is a high, untapped demand for savings opportunities [48]. It demonstrates that there is a high demand for credit and that smallholders resort to different forms of credit such as formal, informal and microfinance, to fulfil their different needs [38]. What is considered hazardous in credit allocation often corresponds to priority needs that are not covered by other credit channels, suggesting the need for flexibility in the lending products and diversity in the credit portfolio [33]. Another observation is that a client's willingness to take out a loan is less determined by the interest rate. Depending on the degree of need at different times of the year and the accompanying conditionalities and facilities, a farmer may choose a loan from an informal lender with a very high interest rate if flexibility for payback is available in case of difficulty [49]. Thus, what appears problematic in the parallel functioning of formal and informal credit markets is related to the farmers' need for fast and flexible credit and the additional costs to the lender of screening, incentivising and enforcing payments. In addition, an empirical study in Indonesia [50] shows that $40 \%$ of those considered unbanked are creditworthy (according to BRI criteria), suggesting that the problem is not so much in the ability of borrowers to service loans [51]. Instead, it is the business model of the lending institutions themselves that is unable to cover the costs of lending. In addition, the agricultural specificities of seasonality that can determine when clients will want to deposit or withdraw funds makes it even harder for the formal sector to adjust and remain profitable [27].

Having explored and appraised the various credit schemes in the literature, the research will now assess how best to implement suitable schemes in the context of a group of farmers. Farmers in many parts of the world have a tradition of working together and exchanging services at specific times of the year. In the case study presented in this research, the farmers dedicate some time to working collectively on communal land. This is important for the interpretation that follows. Credit schemes are often centred on the individual and have been seldom thought of in terms of collectives, or more precisely in terms of the articulation between the individual and the collective, working concomitantly.

\section{Method}

The purpose of the research work was to assess whether a peasant association could self-manage its own credit system with initial seed money, without resorting to an external lending institution. The hypothesis was tested from 2015 to 2019 in a pilot project in Mozambique, Africa, with the farmers' association Alfredo Namitete (AN). 
The method tested self-determination and was non-invasive by nature. The different governing bodies including various committees were formed and strengthened. The regular meetings of the international, national and local committees were systematically recorded and analysed. The model was adjusted and fine-tuned with feedback loops incorporating the information collected from the collective processes, the individual members and the field observations.

\subsection{Identification of the Field Partner}

The União Nacional de Camponeses (UNAC) is the main farmers' organisation in Mozambique, representing 18 million members. UNAC expressed interest in testing the scheme as a step towards finding a new business model to finance a transition to agroecology. A pilot project coordinator and an agroecology technician were selected to support the implementation.

\subsection{Identification of the Farmers' Association}

The selection criteria were defined as follows: a legally registered association established for at least 10 years, mature and responsible, with internal democratic and transparent processes in place, having internal cohesion and good management capabilities, a high degree of participation mechanisms, an ability to work in teams and with experience of collective work.

The process involved numerous back-and-forth consultation meetings and discussions with the decentralised UNAC offices in the Districts and the farmers' associations. In-depth discussions took place with the leaders of the associations and their members (each association has between 20 and 200 members. In total, approximately 750 members were consulted). The Association Alfredo Namitete (AN), in Marracuene, $34 \mathrm{~km}$ North of Maputo was finally selected by UNAC to initiate the pilot project. The association numbered 280 members, with 120 hectares (ha) of individual and communal land. A series of meetings were held to listen to the farmers' feedback on the proposed pilot and to develop the basis for collaborative practice. The study was conducted in accordance with the Declaration of Helsinki, and the protocol was approved by the Ethics Committee of UNAC and the More and Better Network, prior to the study.

\subsection{Collection and Verification of the Data}

The field data was collected by the implementation team through a series of field interviews, field visits and field measures. The pilot coordinator and agroecology technician coordinated the field data collection. It included information on crop varieties, yields, percentage of different crops on the land, percentage and type of crops kept for home consumption and for marketing, prices, nutrition profiles, farm surplus, distance from markets, farm revenue, cost and types of labour, cost of water, energy, pest control, cropping patterns and evolution of farming systems over time. The field data was then reviewed by senior international experts from the Crop Division of the United Nations' Agricultural Department in the Food and Agriculture Organisation (FAO). The process took five months to be completed until all the relevant data was collected, analysed, verified and used for the design of the schemes.

\subsection{Implementation of the Credit Schemes}

The pilot began its operations with AN in October 2015, with seed funding for both a revolving fund (15,000 Euros) and technical assistance (15,000 Euros). It was managed by the UNAC District office in Marracuene. Three credit modalities were proposed and discussed with the association's group of leaders for them to develop their own credit scheme according to their needs and aspirations. One focused on individual investments, one on collective investments and one on both, in addition to a 12-step implementation approach [26]. The 12 steps that were used to implement the scheme included extensive consultation processes with all members of the association, the collective mapping of the local resources, the exploration of new agroecological practices, and discussions on the best ways to reorganise the existing resources to create more local value. It also involved the community defining 
their shared values together, the best ways to strengthen access to resources (land and water) and the importance of creating new links outside the community [52].

Three independent and complementary committees were created to implement the project: an AN association committee, a national implementation committee including UNAC and an international advisory committee composed by world experts and practitioners. The international and national committees agreed that the implementation of the credit schemes would be associated with the following prerequisites: (i) strong, equitable governance; (ii) quality of financial management; (iii) training in agroecology and accounting. The implementation committees followed closely the implementation on the ground with periodic visits and reporting.

\subsection{Field Data and Follow-Up}

The disbursement and use of the loans were organised in the field by the association together with the pilot coordinator and technician. They were monitored regularly with each individual farmer. Farmer-to-farmer agroecology training was provided to 180 members. In addition, three advanced 15-day formal courses were attended by 52 farmers.

The first round of open questionnaires was undertaken at the project's inception in October 2015. Interviews took place on site in farmers' fields. They provided information on households, numbers of children, the year of joining the association, size of land, production, financial practice, plans for changes in cropping patterns and future aspirations. Regular visits to the field were used to collect and treat the data on a continuous basis, both locally and internationally. A second round of questionnaires was undertaken in February 2019 to collect information on the outcomes of the credit schemes. Questions were related to perceptions of the advantages and constraints brought about by the credit schemes, the reasons for participating and the way the credit had been used. Information was collected on changes in cropping patterns and cultivated varieties, the use of inputs and the effects of credit on the total harvest, sales, revenue and social life. Other questions included the repayment status, the opinion of farmers on the collective investments, their wishes for further collective investments, the benefits brought about by the collective garden, the agroecology training, their opinions on how the committees functioned and their future plans.

\section{Results}

\subsection{The First Credit Round}

The credit scheme agreed by the members included individual credit up to a maximum of 10,000 Mzn per person ( 210 Euros at the 2015 exchange rate), for one year, at a 10\% interest rate; and a collective credit for the association up to a maximum of 360,000 Mzn (5000 Euros) with repayment in 5 years, including $30 \%$ of the harvest. The second credit scheme, decided in August 2017, changed the in-kind credit allocation to cash. The amount of the credit became 1500 Mzn ( 21 Euros), with an interest rate of $10 \%$ for 6 months, with the possibility of one extension of 6 months (repayment expected at harvest time), associated with an activity plan describing the use of the funds and monitored by the group of leaders. The first set of rules and regulations attached to the credit contract included rights and obligations are presented in Table 2 as follows:

Table 2. Rules and Regulations.

\begin{tabular}{cccccc}
\hline $\begin{array}{c}\text { Gender in } \\
\text { Decision-Making } \\
\text { Position }\end{array}$ & $\begin{array}{c}\text { Individual } \\
\text { Loans }\end{array}$ & $\begin{array}{c}\text { Collective } \\
\text { Loans }\end{array}$ & Obligations & Transparency & $\begin{array}{c}\text { Breach of } \\
\text { Contract }\end{array}$ \\
\hline $\begin{array}{c}\text { Minimum } 50 \% \\
\text { women. }\end{array}$ & $\begin{array}{c}\text { Loan with } 10 \% \\
\text { interest rate } \\
\text { and 12-month } \\
\text { repayment. }\end{array}$ & $\begin{array}{c}\text { Investment } \\
\text { repaid over 5 } \\
\text { years with } 30 \% \\
\text { on sales. }\end{array}$ & $\begin{array}{c}\text { Agroecology } \\
\text { cultivation and } \\
\text { collective work } \\
\text { on communal } \\
\text { land. }\end{array}$ & $\begin{array}{c}\text { Information } \\
\text { available to } \\
\text { members on crop } \\
\text { volumes, prices } \\
\text { and sales. }\end{array}$ & $\begin{array}{c}\text { First attention } \\
\text { call, and second } \\
\text { suspension as } \\
\text { member. }\end{array}$ \\
\hline
\end{tabular}


- Individual investments

On 28 April 2016, 30 individual members selected by the AN Association Committee signed their individual credit contracts with the UNAC Marracuene office and collected their in-kind inputs (detailed lists were prepared to track deliveries and credit balances). The first list prepared for in-kind credit allocation, as per the farmers' requests, included renting tractor ploughing services, vegetable seeds, roots and tubers, diesel, fertiliser, manure, plastic watering buckets and plastic tubes for the water pump.

The list detailed the items received by the members and the prices. A total of $28 \%$ used $1 / 3$ of the credit allocation, $40 \%$ used $2 / 3,28 \%$ used $1 / 2$, and one person used the totality of the credit. The main seeds distributed were green beans, onion, cabbage and carrot. In the first credit round, farmers complained that there were delays in receiving the seeds and in getting the fields ploughed. Planting dates were becoming increasingly difficult to plan ahead because of climate change. Due to the persistent drought (2015-2016 being amongst the worst recorded years of drought in southern Africa since 1921), coupled with pest outbreaks, soil salinity and low market prices (a kilo of cabbage would sell for the equivalent of 0.04 Euro), the repayment of the loans was slow and erratic. Those who had planted commercial seeds (tomatoes, onions, green beans, etc.) lost the whole of their harvests. The conditions of the farmers' fields showed that their buffer against harvest failure were the traditional, more drought-resistant varieties (roots, tubers, millets, local varieties of onions and maize with a darker thinner cob, etc.).

Borrowers paid the treasurer (who would sit next to the President and Vice President) in small cash amounts at the weekly association meetings. They took place on Thursdays, in the assembly that followed the weekly work in the collective fields. In view of the drought and poor harvests, the AN association committee held an extraordinary meeting. The situation was critical in that some, despite their circumstances, had reimbursed part of their credit so that the remaining balance for those who were unable to do so was not cancelled, but reduced. A decision was made so that $50 \%$ of the remaining balance was written off and no interest rate was to be repaid on the remaining capital. Repayments continued in very small amounts, monitored by the treasurer. Those unable to reimburse were not allowed to access a new loan. The repayment rate for the first group was $37 \%$. There was a waiting list for each new group requesting loans, which were allocated by the leaders depending on who were best placed in terms of need and productive capacity. The treasurer kept records of the repayments of each of the loan rounds with a list of borrowers and the remaining balance.

- Collective investments

In early 2016, collective investments were agreed upon by the implementation committee along with the individual investments. In the first phase, they consisted of a water borehole, water pump, water tank and water tubes, which were purchased and installed. On the production side, two communal areas of land of less than 1 ha each were planted in the first year. The harvests of these communal fields belonged to the community and part of the produce was made available to the members for free or at half price. The money from selling the main part of the harvest was kept by the community to repay the investment and to continue investing collectively. The farmers also learned and tested agroecological practices in the collective fields.

\subsection{The Second Credit Round}

\section{- Individual investments}

On 24 August 2017, a second round of credit was given to a new group of 11 farmers. This time, the group of leaders changed the credit modalities. The new credit was up to $1500 \mathrm{Mzn}$ in cash (equivalent to 21 Euros), with a 10\% interest rate and repayment in the first 6 months with the possibility of one extension of up to 12 months. A Plan of Use of Funds was written and signed by the farmer as an annex to the contract and monitored by the association commission. The risk-sharing mechanism 
with a percentage of repayment based on the harvest was abandoned. The members used the credit mainly to buy seeds of maize, potato, sweet potato, green beans, cabbage, tomato, okra and pepper. The weather was more favourable this year and the farmers were able to produce some harvest. The reasons for changing the credit conditionality were that the goods procured in-kind would not reach the farmers in time. The repayment rate (capital plus interest rate) as of January 2018 was 99\%.

- Collective investments

Investments in the collective fields resulted in a doubling of the communal land being cultivated by the association, reaching 3.7 ha. The functioning of the collective fields meant that each member would work $2 \mathrm{~h}$ per week in them, usually Tuesday, Thursday or Saturday. If the members were unable to work, they had to pay 100 Mzn (approximately 1.4 Euros). The association's rules for collective works are as follows: at the time of harvest, all members are called to work together. They can then buy the produce at a lower rate than the selling price (for example, a cabbage would be sold for $10 \mathrm{Mzn}$ (0.14 Euro) to the members and $20 \mathrm{Mzn}$ to the market). The credit scheme has resulted in the addition of a new collective field, a 1-ha garden surrounding the water borehole which is the main AN meeting area. The collective funds were used to buy fencing materials and crops for the orchard garden. The members were very active in the communal fruit and vegetable garden, which was also used to access drinking water and for leisure time, meetings, communal meals and celebrations.

\subsection{The Third Credit Round}

- Individual investments

On 26 April 2018, a third group of 20 farmers signed the latest version of the credit contract. In this group, two of the 20 borrowers had already accessed and repaid a loan in phase 1. Again, in the 2018 winter period (February to August, with loans taken in April), there were insufficient rains and the farmers suffered another severe drought. In February 2019, the loan repayment rate including interest was $13 \%$.

- Collective investments

In terms of collective investments, cultivation in the collective fields was intensified and new varieties were added. At the end of 2018, the association decided to use credit funds for a new collective investment: a field marketplace, with the idea that it could become the first agroecological market in Mozambique. The plans and the purchasing of materials and building activities were arranged by the AN, then built by the association's members. The building was completed in April 2019.

\subsection{The Alfredo Namitete Bank Accounts}

The latest AN bank statements reflected the collective procurements and expenditures incurred between June 2017 and February 2019, on the decision of the group of leaders and in consultation with their members. They include: fruit tree seedlings, small trees, seeds for the communal garden built around the water borehole and the market point, light fencing material for the communal garden, building materials for the field market, training in accounting and the agroecology courses, the salary of the guard for the water pump and its repair and maintenance. During the 9-month period from November 2017 to August 2018, eight cash deposits of between 9 and 89 Euros were deposited at a total of 30,850 Mzn (430 Euros). In November 2018, a second bank account was opened by the association, as a savings account using money raised from the collective fields and quotas from the members. 


\subsection{Chtiki Agroecology}

In parallel to running the agroecology credit schemes, the association initiated a new credit scheme called Chtiki. Three groups of approximately 20 members met weekly for $30 \mathrm{~min}$ to one hour to deposit savings and borrow smaller amounts for small business purposes. In February 2019, discussions were held about the possibility of converting the agroecology credit scheme into a lending and savings scheme, drawing from some Chtiki functionalities. The idea was well received and approved, and a new business model was designed.

\subsection{The New Credit Business Model}

\section{- The Alfredo Namitete credit system}

The plan for a new AN business model was an investment and savings scheme designed to be self-financing. It would work like the Chtiki, with small groups of approximately 15 farmers meeting weekly to take out loans and make deposits. However, a digital M-PESA account named M-Peasant Agroecology would be used instead of a cash box being kept secretly at the home of a different member each week. Each group would have a designated President and Vice President and a Secretary. At each session, all members would begin by paying their individual contributions to a Climate Fund ( $10 \mathrm{Mzn}$ per week). Members could both deposit and lend money. When members were unable to make repayments of the total + of the agreed interest rate $(\sim 10 \%)$, by the agreed date ( 6 months), they would pay a fine ( $\sim 50 \mathrm{Mzn}$ per each week of delayed payment). At the end of the agreed period ( 12 months), members would receive their initial capital plus interest. The loans could be individual or collective for small groups. In addition, the peasant associations would organise collective savings by collecting a percentage of the sales at the field market point.

\subsection{At the Level of Self-Determination}

Most of the group members had joined the association in two distinct waves in the early to mid-2000 s: $55 \%$ in 2002 and the other $26 \%$ in 2006. Most of the members are women (more than $70 \%$, depending on the groups). The number of children range from 3 to 12, with an average of 4 per household. Regarding the question of their future aspirations, members responded thus: a happy family, health, a rich family, a pickup to transport the crops from the field, a good house, a well-established business, happy grandchildren and better ways of life. The main observations regarding conditions on the farm were the lack of water for irrigating crops, salination and low market prices.

With respect to discussions in the various committees, members highlighted the importance of not creating a gap between those who did or did not have access to credit, as the objective of the association was to progress step by step to give access to all. Regarding control measures within the association, the President explained that some members were not attending the weekly association meetings on Thursdays, nor coming to work in the collective plots, which was a violation of the association's statutes equivalent to not paying the annual quota or having plots in two associations at the same time, thus creating conflicts on the land. Members also had some concerns about the penalties for the non-repayment of credit. The contract signifies that first there is an "attention call" and then the person can be "suspended from the association". In practice however this did not happen. The association also holds a solidarity fund from the proceedings of collective sales which is used for those in need (such as poor health or a special family situation). During the drought, alternative ways for income generation were devised and discussed. The AN President suggested selling water from the borehole to help bring funds to the community and finance the purchase of more water pipes to bring water to the surrounding fields.

In practice the AN's internal association committee was more dynamic compared to the implementation committee which included the UNAC District office. It had reinforced itself over the years, becoming a permanent commission of the AN association. The implementation committee was instrumental during the first 16 months to facilitate the procurement and delivery of goods and 
services for the individual and collective investments, the follow-up of the construction processes and the initial financial management of the pilot. In February 2017, UNAC Marracuene handed over the management and financial responsibilities to the AN association. The UNAC focal point became the only external advisor to the AN association and pursued a close follow-up of the testing of the credit schemes and related field activities. The international advisory committee provided backstopping to the project until March 2017. After that date, the steering committee became an advisory committee that could be consulted as and when needed, on an ad-hoc basis.

A turning point in the functioning of the credit schemes was the opening of the AN association account on 13 March 2017. This required some work by the members to legalise and update their association's registration. When the account was opened and UNAC transferred the balance of the pilot, the association became the sole decider on the movements of funds. There were 4 designated signatories for the account (three women and one man). The bank account started with a balance of 346,000 Mzn (approx. 4900 Euros), to which the More and Better added 367,229 Mzn (5130 Euros) in April 2018 for technical assistance. The project's accounts were audited by UNAC Headquarters in November 2016, with satisfying results despite some discrepancies in the amounts distributed in terms of seeds and cement. There was also a conflict with a company that had been paid to clean the water canals with moneys reserved by the collective credit allocation but had not done the work. Following the hand-over of management functions in 2017, the AN association created its own internal commissions as follows: Implementation Commission; Finance Sub-Commission; Procurement and Sales Sub-Commission; Training Sub-Commission, and Production Sub-Commission. The AN association then prepared a detailed 2018-2023 Strategy Plan approved by all the members at their General Assembly.

The summary feedback on the questionnaires showed a majority of responses expressing satisfaction with the credit schemes, the importance of being able to repay in several installments, a general satisfaction with the practice of agroecology, an increase in revenue estimated at approximately $20 \%$, an increase in the diversity of crops in the fields and finally an appreciation of working in the collective fields as a place for collective learning about new farming practices. On the possible improvement side, it was noted that the amounts were too small to make a real difference, that it was difficult to continually clear the fields of thick bush and there was also a wish to access new credit for animals, carts and tractors to bring the crops from the fields to the marketplace. The farmers explained that they were now able to pay for their children to attend school and have lunches. They were also able to carry out some home repairs.

The characteristics and results are presented respectively in Tables 3 and 4 as follows: 
Table 3. Characteristics as per cluster criteria.

\begin{tabular}{|c|c|c|c|c|c|}
\hline & Collateral & Distance (D) & Time for Loan Approval & Transaction Costs & $\begin{array}{c}\text { Flexibility on Repossession of } \\
\text { Assets and Admin Work }\end{array}$ \\
\hline $\begin{array}{l}\text { Three credit rounds } \\
04 / 2016 \\
08 / 2017 \\
04 / 2018\end{array}$ & $\begin{array}{l}\text { No collateral required. } \\
\text { Criteria defined by group } \\
\text { of leaders on ability to } \\
\text { repay back loan. }\end{array}$ & $\begin{array}{l}\text { No distance. Loan } \\
\text { provided in kind for the } \\
\text { first round and in cash for } \\
\text { the other two rounds at } \\
\text { farmers' weekly meeting } \\
\text { point in field. }\end{array}$ & $\begin{array}{l}\text { One week between } \\
\text { submission of candidates } \\
\text { to loan, and approval by } \\
\text { group of leaders. }\end{array}$ & $\begin{array}{l}\text { No transaction costs. } \\
\text { These are covered by the } \\
\text { group of leaders as part of } \\
\text { their governance tasks. }\end{array}$ & $\begin{array}{l}\text { No case of suspension of } \\
\text { members in any of the credit } \\
\text { rounds. Leaders keep close } \\
\text { monitoring of individual } \\
\text { members. No extra admin } \\
\text { work. }\end{array}$ \\
\hline
\end{tabular}

Table 4. Results (Sustainable Development Goals criteria).

\begin{tabular}{|c|c|c|c|c|}
\hline & Economical & Social & Environmental & Governance \\
\hline $\begin{array}{l}\text { First credit round } \\
04 / 2016 \\
\text { Serious drought in the south of } \\
\text { Africa. }\end{array}$ & $\begin{array}{l}\text { Collective } \\
\text { Built water borehole (pump, tank, } \\
\text { building), access drinking and } \\
\text { irrigation water; } \\
\text { Land preparation and planting } 2 \\
\text { communal fields; } \\
\text { Training } 2 \text { accountants + } 5 \text { trainers in } \\
\text { agroecology (AE). } \\
\text { Individual } \\
\text { Land converted to AE, increase crop } \\
\text { diversity and sales; } \\
37 \% \text { loan repayment rate; } \\
\text { Adjust loans from in-kind to cash and } \\
\text { divide amount by } 10 \text { (max } \sim 21 € \\
\text { equivalent instead of } 210 € \text { equiv). }\end{array}$ & $\begin{array}{l}\text { Based on visits and } \\
\text { questionnaires*: } \\
20 \% \text { increase in revenue used } \\
\text { for school fees, school lunches, } \\
\text { home repairs; } \\
\text { Better quality/diversity in } \\
\text { nutrition (estimate increase } \\
\text { from } 1886 \mathrm{kcal} / \text { pers/day to } 2100 \\
\mathrm{kcal} / \text { pers/day); } \\
\text { No chemical health injury as } \\
\text { previously the case; }\end{array}$ & $\begin{array}{l}\text { Emphasis on rebuilding soil life } \\
\text { and structural qualities. } \\
\text { Regenerating soils bringing } \\
\text { back natural soil organisms and } \\
\text { beneficial fungi; } \\
\text { Recovering natural wild fauna } \\
\text { and flora; } \\
\text { Carbon sequestration increase } \\
\text { with AE practice (estimate } \\
\text { increase by } 7520 \mathrm{t} \text { CO2e over } \\
20 \text { years and reduction of carbon } \\
\text { emissions by } 18,880 \mathrm{t} \text { CO2e). }\end{array}$ & $\begin{array}{l}\text { With the project, an Extraordinary } \\
\text { General Assembly was held to elect the } \\
\text { Governing Bodies **: } \\
\text { 1-Executive Council (President Female (F), } \\
\text { Vice President F, Secretary Male (M)); } \\
\text { 2-Financial Council (President M, } \\
\text { Vice-Secretary F, Assistant F); } \\
\text { 3-General Assembly Table (President M, } \\
\text { Vice President M, Secretary F); } \\
\text { In addition, the Alfredo Namitete (AN) } \\
\text { Association created an Implementation } \\
\text { Commission for the project (Chief M, } \\
\text { Associate Chief F, Secretary F), and } 4 \\
\text { Sub-Commissions: } \\
\text { 1-Accounting (lead F); } \\
\text { 2-Production (lead M); } \\
\text { 3- Procurement and Sales (lead F); } \\
\text { 3-Training (lead M). } \\
\text { AN designed a Strategy Plan 2018-2023 } \\
\text { discussed and approved by the members of } \\
\text { the Association, currently under } \\
\text { implementation. } \\
\text { Total: 56\% women in leading positions. }\end{array}$ \\
\hline
\end{tabular}


Table 4. Cont.

\begin{tabular}{|c|c|c|c|c|}
\hline & Economical & Social & Environmental & Governance \\
\hline $\begin{array}{l}\text { Second round } \\
\text { 08/2017 } \\
\text { Rains normalize. }\end{array}$ & $\begin{array}{l}\text { Collective } \\
\text { Built collective orchard (plant fruit trees, } \\
\text { veg, agroforestry structure-pineapple, } \\
\text { orange, mango) fenced; } \\
\text { Training } 90 \text { farmers in AE; } \\
\text { AE produce sold on neighboring } \\
\text { markets with added value/premium } \\
\text { price. } \\
\text { Individual } \\
\text { Increase land in AE, diversify crops, } \\
\text { new seeds veg with high price on } \\
\text { market; } \\
20 \% \text { increase in sales; } \\
99 \% \text { loan repayment rate; } \\
\text { Open first bank account. }\end{array}$ & $\begin{array}{l}\text { More time spent collectively } \\
\text { learning and sharing } \\
\text { knowledge on AE practices in } \\
\text { communal field; } \\
\text { More consumption of fruits } \\
\text { from collective garden which is } \\
\text { distributed during collective } \\
\text { meals and sold at a reduced } \\
\text { price to members; }\end{array}$ & $\begin{array}{l}\text { Plan to clean water canals; } \\
\text { Water contamination with } \\
\text { nitrates reduced; } \\
\text { Farmers speak of seeing } \\
\text { increased wild birds and } \\
\text { butterflies and plan dev honey } \\
\text { production; } \\
\text { Planning a scientific } \\
\text { botanical/wildlife survey. }\end{array}$ & \\
\hline $\begin{array}{l}\text { Third round } \\
\text { 04/2018 } \\
\text { Drought in South Africa region. }\end{array}$ & $\begin{array}{l}\text { Collective } \\
\text { Built marketplace (market structure } \\
\text { built with help of members); } \\
\text { Collective land doubled size; } \\
\text { Formal registration of association } 120 \\
\text { ha land to secure rights; } \\
\text { Training additional } 90 \text { farmers in AE. } \\
\text { Individual } \\
\text { Land preparation and AE cultivation. } \\
\text { 13\% repayment rate; } \\
\text { Open second bank account; } \\
\text { Start new business lending and savings } \\
\text { scheme: Chtiki. }\end{array}$ & $\begin{array}{l}\quad \text { Increased social cohesion } \\
\text { with more time spent } \\
\text { collectively; } \\
\text { Increased participation in } \\
\text { self-determination (discussing } \\
\text { the new 2018-2023 Association } \\
\text { Strategy Plan); } \\
\text { Increased confidence by the fact } \\
\text { of having own bank accounts, } \\
\text { gives a sense of security. } \\
\text { Opened a solidarity account to } \\
\text { help members in case of need. }\end{array}$ & $\begin{array}{l}120 \text { ha of land now with no } \\
\text { chemical pesticides, herbicides, } \\
\text { fungicides; } \\
120 \text { ha of land with no chemical } \\
\text { fertilizers. } \\
\text { Permanent soil cover, with crop } \\
\text { residue and green mulching. }\end{array}$ & \\
\hline
\end{tabular}

* Included questions based on the nine domains of the Global National Happiness (GNH) Index, i.e., psychological wellbeing, health, education, time use, cultural diversity and resilience, good governance, community vitality, ecological diversity and resilience, and living standards. ${ }^{* *}$ Before the project the group of leaders was only formed by President, Vice President, and Secretary. The election of the new governing structure allowed to register legally the association and to open an association bank account. 


\section{Discussion}

\subsection{Contrasting with the Literature}

The findings are consistent with Laureti [48] in the fact that the poor are financially very active. The association was able to successfully manage its own credit fund independently when it received the initial seed funding and was able to open its own bank account for the first time. It took full responsibility for the disbursement and monitoring of the loans and organised three rounds of credit allocation. It later opened and managed a second bank account with the savings from the collective harvests and the contributions of the members. In addition to the loan schemes dedicated to agroecology, it initiated its own new scheme for lending and saving for small businesses. The long waiting list of farmers applying for credit suggests that there is a high demand. The fact that some of those who had accessed and repaid loans in the first round were requesting loans a second time, confirms the findings of Johnston and Morduch [50], suggesting that a substantial number of borrowers below the poverty line are potentially creditworthy and that much of the problem rests in the ability of the lending institutions to provide loans. For each credit round, the group of elected leaders had a well-defined process of selection of beneficiaries. When the harvests were low, the leaders added flexibility to the repayment schedule and reduced the amounts to be repaid on a case-by-case basis.

The increased autonomy and strengthened decision-making power of the AN, which was able in 2018 to resist external pressure from a foreign corporation requesting the land for a commercial sugar cane plantation, demonstrates the following. Providing seed funds and the reins for self-management and local decision making triggers local development and unleashes a significant potential. This aligns with the importance of the Raiffeisen 3 S approach (Self-help, Self-government, Self-responsibility) and the People's Banks described by Turvey [37] in his historical review of agricultural finance. It also confirms Seibel [39], describing the success of BRI in Indonesia (i.e., new organisational systems away from donor and government-supported programmes). The association started slowly at the beginning of the pilot with individual investments and one collective investment (the water borehole). As time passed, the pace and intensity of investments increased substantially and there was a turning point when the association had full control over its own bank account. The surface area of the collective land doubled, the time spent on collective works increased accordingly and the speed and amounts of investments all accelerated; in seeds, planting materials, ploughing and levelling the land, building the marketplace and fencing and planting the collective garden. There was a perceptible dynamic effervescence that grew as the practice of lending became more familiar to the group of leaders.

The group of leaders was observed to be closely monitoring the use of the funds. They also designed specific instruments to facilitate guidance and supervision. This confirms the need for screening, incentives and enforcement, as identified by Hoff and Stiglitz [49]. In effect, following consultations about the results of the first round of credit, the association committee designed a new credit scheme with smaller amounts than in the first round of loans. They added a new document to the loan contract to be signed by the farmers which was a plan for the use of the funds, which again, they closely monitored. The association also controls the hours of collective work in the common fields. The farmers use this time to learn about agroecological practices and after applying them in own fields, are able to provide feedback to the group. Harvests from the communal fields are used for collective investments. Increasing collective savings with the collection of a percentage of sales is now possible with the construction of the new field market point, which aggregates produce in one place.

The findings show that the repayment rate of individual credit is directly related to rainfall and harvest and is not dependent on the will of the borrower. It seems irrelevant to add further layers of control and forceful repayment because the equation is straight forward: no rains, no harvest, no repayment. During conversations with farmers when completing the questionnaires, they explained that they resort to other creative ways to make repayments. One lady for example was buying bread and selling sandwiches in the streets at lunch time to repay the loan little by little. The first credit was the most difficult to pay back as the amounts were higher and it was followed by drought. Farmers 
however mitigate the risk by keeping seeds as a reserve for better times. When climate avails (as in the second round of credit), the reimbursement would come closer to $100 \%$. The interest rate does not seem to be of prime importance or concern. The main concern, as presented by Jia, Luan, Huang and $\mathrm{Li}$ [40], is the flexibility of repayment (in time and in amounts), and the possibility of access to small amounts at the right time, when needed. In addition, the importance of attenuating circumstances for borrowers and technical assistance matches the situations found in the credit schemes in Costa Rica [43], as well as the Homeland Coffers [38], whereby flexibility and solidarity funds act as a buffer in case of need.

The results in the field demonstrate that with minimal seed funding and training, farmers are able to intensify their production. The farmers reported an estimated increase of approximately $20 \%$ in production and an increase in revenue. They reported that their produce was better accepted in the market and that the consumers recognised and showed a preference for chemical-free produce (it was reported as better tasting). In this respect, it can be argued that given enabling conditions, smallholders are able to intensify their production, which translates into better revenue. To this end, an emphasis on policies that lead to a favourable sustainable agricultural production environment should be encouraged, rather than stepping in later with poverty reduction programs [34].

In addition to reporting on individual investments, the findings show the importance of collective investments. In terms of collective practice, the farmers' association significantly increased its collective work which also translated into increased social events and regular platforms for consultations and communal decision making. The transformations that took place during the pilot were recounted by the members and incorporated into their songs and spiritual practices. This gives a clear indication of the importance of collective resources for the community. In this sense, the privatisation of land to increase credit access, as recommended by Qin, Wachenheim, Wang and Zheng [41], would not be recommended. Both the collective and individual lands, as testified by AN members, are places for adaptation, fine-tuning and testing that play a crucial role within the community. They are also important for climate mitigation and adaptation and a place for in situ conservations about crop varieties that can evolve and adapt. Thus, policy efforts to transform smallholders from subsistent into commercially driven and market responsive farmers, as suggested by Musah Abu and Haruna [31], would not be encouraged as diversity in crops and flexibility in agronomical practices are important to strengthen autonomy and self-determination.

Based on the above results, it can be argued that in order to be successful, a smallholder credit scheme needs a number of conditions to be simultaneously met. These conditions are as follows.

- Believe in the genuine will to repay

To believe in the genuine will to repay back loans and organise the credit around trust rather than control. Trust implies putting the lender's costs, time and energy into facilitating mechanisms to accompany the farmers. These include, but are not limited to: (a) agreeing on rules of compliance that are perceived as being fair and acceptable to the borrower; (b) a contract should be drafted by the borrower, with the help of community leaders if needed, to specify the planned use of the loan, verifiable by peer-review or group leaders' procedures; (c) experimental training on agroecology; and (d) a solidarity mechanism in case of personal impediment.

- Abolish the lender-borrower distance

To cancel the distance (both physical in terms of $\mathrm{km}$, and mental in terms of the power imbalance) between lender and borrower. Both should be located within the farmers' association, with the scheme managed by a group of democratically elected leaders.

- Ensure a role for women in decision making

To bring a female perspective to the collective decision-making mechanism (a group of leaders with at least $50 \%$ women). The presence of more than $50 \%$ of women in the decision-making instances 
of the pilot have been found to influence choices in collective investments to favour family and community well-being over and above the search for increased profit, per se.

- Add a savings mechanism

To add a savings mechanism to bring enough capital to be self-financing. In the case of the Homeland Coffers, the most relevant example of agricultural credit systems found in the literature review, the funds were collected from $5 \%$ of the farmers' production, joint cultivation of high yield crops (half an acre per household) of fallow and unused land, $15 \mathrm{~kg}$ of cereals from farmers in a position to contribute, with the types and amounts of products collected depending on the region and fees for the administration of the fund. In the case of AN, its members' work in the collective fields provides the capital (after sales following the harvest) for the common savings account. The marketplace has been built for that same purpose, with the idea of collecting a percentage of sales to serve the community.

- Combine individual and collective investments

To combine individual and collective investments and practices. Collective works were already a well-accepted and familiar practice for AN members. Farmers in the project were able to see, practice, learn and adapt agroecology practices in the communal land (where they work together every week), then apply them in their own fields. It is also a place of exchange of knowledge where they share their own issues (such as pests, soil fertility and water). Collective and individual practice is also highlighted in the literature in the case of the Homeland Coffers.

- Reserve funds for solidarity and climate issues

To reserve funds for solidarity and climate issues. The solidarity funds already exist in many credit mechanisms. They are found in the Costa Rica example of public credit systems, in the Homeland Coffers and in a diverse form in the Grameen Bank, known as simultaneous social agenda.

\subsection{The Fifth Business Model}

These characteristics can form the basis of a fifth cluster of credit models following those described in Section 1. The first was characterised by collateral, distance, power imbalance, high transaction costs, tight control, lengthy administrative procedures and limited sharing of information. It was a vertical dependency, with capital leaving the community (formal credit schemes) The second was schematised by formal credit and centralised with field branches, flexibility in collateral and repayment, having a vertical structure, with technical assistance, savings and flexibility (BRI [39], Costa Rica [43]). The third had no collateral, relied on trust, group lending, peer-pressure on borrowers, loan-for-business or microenterprise, the use of loans for both consumption and production, the closeness of bank staff with the borrowers, cooperative principles and a horizontal structure (Raiffeisen [37], Grameen Bank [51], CFPA [40]). The fourth was characterised by capital accumulation for self-financing, combining four components: savings, lending, investment in infrastructure and solidarity, plus the possibility to transfer funds from one fund to another in case of need (Homeland Coffers [38]).

The suggested fifth model is characterised by having no collateral, merging the place of lending and borrowing and being the responsibility of the farmers' association leaders. It has self-management, flexibility, transparency and close field monitoring; but is without distance, transaction costs, administrative paperwork and waiting times for loan approval. It includes capital accumulation, lending, governance ( $50 \%$ at least should be women), individual and collective investments, solidarity and climate reserves and technical assistance. It starts with a one-off injection of capital $(15,000$ Euros + 15,000 Euros for technical assistance). The pre-conditions are existing associations that have democratic processes of electing their leaders. The place of capital accumulation and lending is the same and its success is based on connected individual and collective investments under solid governance and supported by agroecology training. 


\section{Conclusions}

The experience of the Alfredo Namitete farmers' association in managing, adapting and designing its own credit schemes has resulted in tangible individual and collective investments, with diverse, increased harvests and stronger self-determination and pride, in addition to contributing to the knowledge of credit systems. This small, peasant community now has a sense of extended horizons, with the possibility of planning for the future. The study confirms the findings by authors in the literature that the problem of the unbanked lies in the practices of the lending institutions [50], and that the poor themselves have very active financial lives [48]. It also confirms the need for flexibility, as repeatedly stated by the reviewed authors and the importance of having access to loans for production and for consumption [40]. It has demonstrated the extent to which very small amounts of capital can be crucial at key points in time.

On the basis of this research, it is argued that to be successful, a peasant farmer's credit scheme needs a number of conditions to be met simultaneously: replace control by trust and organise credit around the genuine will to repay loans (with facilitating mechanisms); cancel the distance between lender and borrower (physical and mental); bring women into the collective decision making; add a savings mechanism to bring sufficient capital for self-financing [38]; combine the individual and the collective; and reserve funds for solidarity and climate issues. All these factors need to be grounded in solid governance.

Finally, to take these considerations a step further, it would be interesting to reflect on the possibility of connecting the different funds, as was the case in the example of the Homeland Coffers [38]. This would form a larger web of funds that could buffer each other. This could then be the beginning of a transition away from large, centralised lending institutions, towards more horizontal and generalised access to resources, that could contribute to the well-being of human societies at large.

Funding: This research received funding from Coventry University Innovation Fund and from the More and Better Network (Heidehoff Foundation).

Acknowledgments: Renaldo Chingore, UNAC focal point, played a key role in the success of the pilot. Aksel Naerstad from the More and Better Network, and Michael Shaw from Biomatrix Water Solutions, contributed to the pilot as members of the Advisory International Committee. International experts and practitioners (Hans Herren, Jan Douwe van der Ploeg, Jean Marc von der Weid) provided expertise on an ad hoc basis during the pilot implementation. Sertac Dokuzlu added information on Homeland Coffers. Holly Singleton assisted with the literature.

Conflicts of Interest: The authors declare no conflict of interest.

\section{References}

1. IAASTD. International Assessment of Agricultural Knowledge, Science and Technology_Global Report; Island Press: Washington, DC, USA, 2009.

2. Herren, H.R.; Hilbeck, A.; Hoffmann, U.; Home, R.; Levidow, L.; Muller, A.; Nelson, E.; Oehen, B.; Pimbert, M. Feeding the people: Agroecology for Nourishing the World and Transforming the Agri-Food System; IFOAM EU Group: Brussels, Belgium, 2015.

3. Hilmi, A. Peasant Farming as a Source of Life. In Development (Basingstoke); Springer: Berlin/Heidelberg, Germany, 2018.

4. Koohafkan, P.; Altieri, M.A. Globally Important Agricultural Heritage System: A Legacy for the Future; Food and Agriculture Organization of the United Nations: Quebec, QC, Canada, 1945.

5. Pretty, J. Agri-Culture. Reconnecting People, Land and Nature; Earthscan: London, UK, 2013.

6. The Development Fund. A Viable Food Future; The Development Fund: Oslo, Norway, 2011.

7. Godfray, H.C.; Beddington, J.R.; Crute, I.R.; Haddad, L.; Laurence, D.; Muir, J.; Pretty, J. Food Security: The Challenge of Feeding 9 Billion People. Science 2010, 327, 812-818. [CrossRef] [PubMed]

8. Hilmi, A.; Burbi, S. Peasant farming, a buffer for human societies. Development 2015, 58, 346-353. [CrossRef]

9. Hilmi, A.; Burbi, S. Peasant farming, a refuge in times of crises. Development 2016, 59, 229-236. [CrossRef] 
10. Altieri, M.A.; Funes-monzote, F.R.; Petersen, P. Agroecologically efficient agricultural systems for smallholder farmers: Contributions to food sovereignty. Agron. Sustain. Dev. 2012, 32, 1-13. [CrossRef]

11. Kulyk, P.; Grzelak, A. Investments in agricultural holdings in the EU (10) countries by the prism of the Michal Kalecki's business cycle theory. Econ. Sci. Rural Dev. 2018, 468. [CrossRef]

12. Lowder, S.K.; Carisma, B.; Skoet, J. Who Invests How Much in Agriculture in Low-and Middle-Income Countries? An Empirical Review. Eur. J. Dev. Res. 2015, 27, 371-390. [CrossRef]

13. ETC Group. Who-Will-Feed-Us? Questions for the Food and Climate Crises; ETC Group: Durham, NC, USA, 2009.

14. HLPE. HLPE. High Level Panel of Experts. Investing in smallholder agriculture for food security. In Proceedings of the FAO Conference on World Food Security, Rome, Italy, 24 May 2013.

15. Binswanger, H.P.; Sillers, D.A. Risk Adversion and Credit Constraints in Farmers' Decision Making: A reinterpretation. J. Dev. Stud. 1983, 20, 5-21. [CrossRef]

16. Palmi, P.; Morrone, D.; Paolo Miglietta, P.; Fusco, G. How Did Organizational Resilience Work Before and after the Financial Crisis? An Empirical Study. Int. J. Bus. Manag. 2018, 13, 54-62. [CrossRef]

17. IFAD. Responding to Land Grabbing and Promoting Responsible Investment in Agriculture; IFAD: Rome, Italy, 2011.

18. Cotula, L. Land Grab or Development Opportunity? Agricultural Investment and International Land Deals in Africa; IIED: London, UK; FAO: Quebec, QC, Canada; IFAD: Rome, Italy, 2009.

19. Cotula, L.; Leonard, R. Alternatives to Land Acquisition: Agricultural Investment and Collaborative Business Models; IIED: London, UK; IFAD: Rome, Italy; CTV: Maputo, Mozambique, 2010.

20. Cotula, L.; Leonard, R. Investing in Partnership: Agricultural Investments and Collaborative Business Models; IIED: London, UK; IFAD: Rome, Italy; SDC: Bern, Switzerland; CTV: Maputo, Mozambique, 2010.

21. Kissinger, G. Alternative Investment Models of Sustainable and Inclusive Agriculture in Developing Countries: A Discussion Paper; Lexeme Consulting: Vancouver, BC, Canada, 2012.

22. FAO. Principles for Responsible Agricultural Investment That Respects Rights, Livelihoods and Resources; FAO: Rome, Italy, 2012.

23. Vermeulen, S.; Cotula, L. Making the Most of Agricultural Investment: A Survey of Business Models that Provide Opportunities for Smallholders, 2010. Survey of Business. Available online: http://www.fao.org/ docrep/012/al297e/al297e00.pdf (accessed on 26 July 2019).

24. Miller, C.; Richter, S.; McNellis, P.; Mhlanga, N. Agricultural Investment Funds for Developing Countries; FAO: Rome, Italy, 2010.

25. Lowder, S.K.; Skoet, J.; Singh, S. What Do We Really know about the Number and Distribution of Farms and Family Farms Worldwide? Background Paper for The State of Food and Agriculture 2014, (14). Available online: http://www.fao.org/docrep/019/i3729e/i3729e.pdf (accessed on 8 April 2014).

26. Binswanger, H.P.; Rosenzweig, M.R. Behavioural and Material Determinants of Production Relations in Agriculture. J. Dev. Stud. 1986, 22, 503-539. [CrossRef]

27. Nagoev, A.B.; Republic, K.; Rokotyanskaya, V.V.; Stolyar, I.V.; Kulyakina, E.L. Role of the State in the Distribution and Redistribution of Cash and Agricultural Resources in the Regions of the Russian Federation. Iraqi J. Agric. Sci. 2019, 50, 143-151.

28. Hilmi, A. Agroecology: Reweaving a New Landscape; Coventry University: Coventry, UK, 2017.

29. Pimbert, M. Agroecology as an alternative vision to conventional development and climate-smart agriculture. Development 2015, 58, 286-298. [CrossRef]

30. Giraldo, O.F.; Rosset, P.M. Agroecology as a territory in dispute: Between institutionality and social movements. J. Peasant Stud. 2018, 45, 545-564. [CrossRef]

31. Abu, B.M.; Haruna, I. Financial inclusion and agricultural commercialization in Ghana: An empirical investigation. Agric. Financ. Rev. 2017, 77, 524-544. [CrossRef]

32. Nguyen, T.T.; Nguyen, L.D.; Lippe, R.S.; Grote, U. Determinants of Farmers' Land Use Decision-Making: Comparative Evidence From Thailand and Vietnam. World Dev. 2017, 89, 199-213. [CrossRef]

33. Sabbaghi, M.A. Moral Hazard in the Use of Agricultural Credits by Iranian Farmers: A Case Study Dezful Township. Sci. Pap. Ser. Manag. Econ. Eng. Agric. Rural Dev. 2017, 17, $29-34$.

34. Yuan, Y.; Xu, L. Are poor able to access the informal credit market? Evidence from rural households in China. China Econ. Rev. 2015, 33, 232-246. [CrossRef]

35. Afrin, S.; Haider, M.Z.; Islam, M.S. Impact of financial inclusion on technical efficiency of paddy farmers in Bangladesh. Agric. Financ. Rev. 2017, 77, 484-505. [CrossRef] 
36. Ahmad, D.; Chani, M.I.; Afzal, M. Impact of Formal Credit on Agricultural Output: Empirical Evidence from Pakistan. Sarhad J. Agric. 2018, 34. [CrossRef]

37. Turvey, C.G. Historical developments in agricultural finance and the genesis of America's farm credit system. Agric. Financ. Rev. 2017, 77, 4-21. [CrossRef]

38. Dokuzlu, S. The Agricultural Credit System in the Ottoman Empire between 1863 and 1888. Rural Hist. 2017, 28, 177-188. [CrossRef]

39. Seibel, H.D.; Rachmadi, A.; Kusumayakti, D. Reform, Growth and Resilience of Savings-Led Commercial Microfinance Institutions: The Case of The Microbanking Units of Bank Rakyat Indonesia. Sav. Dev. 2019, 34, 277-303.

40. Jia, X.; Luan, H.; Huang, J.; Li, Z. A comparative analysis of the use of microfinance and formal and informal credit by farmers in less developed areas of rural China. Dev. Policy Rev. 2015, 33, 245-263. [CrossRef]

41. Qin, M.; Wachenheim, C.J.; Wang, Z.; Zheng, S. Factors affecting Chinese farmers' microcredit participation. Agric. Financ. Rev. 2019, 79, 48-59. [CrossRef]

42. Grisa, C.; Buchweitz, V.D. Revista de Economia e Sociologia Rural Revisitando o Pronaf: Velhos questionamentos. Rev. De Econ. E Sociol. Rural 2018, 52, 323-346. [CrossRef]

43. INDAP, A. Balance de Gestion Integral Ano; INDAP: Santiago, Chile, 2019.

44. Robinson, M.S. The Microfinance Revolution: Lessons from Indonesia; The World Bank: Washington, DC, USA, 2002.

45. Tomilova, O.; Dokle, E. CGAP Funder Survey 2017: Trends in International Funding for Financial Inclusion, 2019, (Symbiotics 2017), 4. Available online: https://www.cgap.org/sites/default/files/publications/BriefCGAP-Funder-Survey-2017-Jan-2019.pdf (accessed on 26 July 2019).

46. Hilmi, A.; Naerstad, A. Investments in Small-Scale Sustainable Agriculture; The More and Better Network: Oslo, Norway, 2017.

47. Gebremariam, Y. Small Loans, Big Dreams: How the Nobel Prize Winner Muhammad Yunus and Microfinance are Changing the World, edited by Alex Counts. East. Econ. J. 2008, 36, 142-144. [CrossRef]

48. Laureti, C. Why Do Poor People Co-Hold Debt and Liquid Savings? J. Dev. Stud. 2018, 54, $213-234$. [CrossRef]

49. Stiglitz, J.E. Peer Monitoring and Credit Markets. World Bank Econ. Rev. 2018, 4, 351-366. [CrossRef]

50. Johnston, D., Jr.; Morduch, J. The unbanked: Evidence from Indonesia. World Bank Econ. Rev. 2018, 22, 517-537. [CrossRef]

51. Varghese, A. The Microfinance Revolution: Sustainable Finance for the Poor. J. Asian Econ. 2002. [CrossRef]

52. Hilmi, A. Agricultural Transition, a Different Logic; The More and Better Network: Oslo, Norway, 2012. 